\title{
PEMANFAATAN ASAP CAIR DARI PIROLISIS CANGKANG KELAPA SAWIT SEBAGAI PENGAWET ALAMI TAHU
}

\author{
Lisa Ginayati $^{1}$, M. Faisal $^{2 *}$, Suhendrayatna ${ }^{2}$ \\ Prodi Magister Teknik Kimia, Universitas Syiah Kuala, Darussalam Banda Aceh ${ }^{1}$, \\ Jurusan Teknik Kimia, Universitas Syiah Kuala, Darussalam, Banda Aceh ${ }^{2}$ \\ *E-Mail:mfaisal@unsyiah.ac.id
}

\begin{abstract}
Abstrak
Penelitian ini bertujuan untuk memanfaatkan limbah cangkang sawit untuk diolah menjadi asap cair grade I yang digunakan sebagai pengawet alami tahu. Proses yang digunakan untuk menghasilkan asap cair adalah dengan menggunakan metode pirolisis. Temperatur pirolisis yang digunakan adalah $300^{\circ} \mathrm{C}, 340^{\circ} \mathrm{C}$ dan $380^{\circ} \mathrm{C}$. dengan konsentrasi asap cair : $0,5 \%, 1 \%, 2 \%$, $4 \%$, dan $6 \%$. Pemurnian asap cair dari grade III menjadi grade I dilakukan melalui dua tahap distilasi pada temperatur $200^{\circ} \mathrm{C}$. Asap cair grade I yang dihasilkan kemudian digunakan untuk mengawetkan tahu agar dapat meningkatkan masa simpan tahu. Pengujian ketahanan tahu yang diawetkan dilakukan dengan Total Volatile Base (TVB) dan Organoleptik. Berdasarkan uji nilai TVB, tahu dapat bertahan selama 56 jam apabila direndam dengan asap cair, sedangkan ketahanan tahu yang tidak direndam dengan asap cair hanya 16 jam. Uji organoleptik yang dilakukan menunjukkan $90 \%$ responden menyukai rasa, aroma dan tekstur tahu yang direndam dengan asap cair yang dipirolisis pada temperatur $340{ }^{\circ} \mathrm{C}$ dengan konsentrasi $0,5 \%$. Nilai TVB pada kondisi tersebut adalah $19,61 \mathrm{mgN} \%$.
\end{abstract}

Kata kunci : cangkang sawit, pirolisis, asap cair, tahu, pengawet alami, organoleptik, total valatile base (TVB)

\begin{abstract}
This research aims to utilize the coconut-palm shell waste to be processed as liquid smoke grade I, used for natural preservative of tofu. The process used to produce the liquid smoke is by using pyrolysis method. The pyrolysis temperatures used ware $300^{\circ} \mathrm{C}, 340^{\circ} \mathrm{C}$, and $380^{\circ} \mathrm{C}$, with liquid smoke concentration of $0.5 \%, 1 \%, 2 \%, 4 \%$, and $6 \%$. Purification of liquid smoke from grade III to grade I was made through two distillation phases at temperature of $200^{\circ} \mathrm{C}$. The produced liquid smoke grade I was then utilized to preserve the tofu in order to increase its storing period. The testing towards durability of the preserved tofu was done by Total Volatile Base (TVB) and Organoleptic. Based on the TVB values test, the tofu can last for 56 hours when it was soaked in liquid smoke, while the durability of the tofu without soaked in liquid smoke was only 16 hours. Results of the organoleptic test showed that 90\% of respondents favor the taste, flavor, and texture of the liquid smoke-soaked tofu, which was pyrolysed at $340^{\circ} \mathrm{C}$ and at concentration of $0.5 \%$. the TVB Value at these condition was $19.61 \mathrm{mg} \mathrm{N} \%$.
\end{abstract}

Keywords: coconut-palm shell, pyrolysis, liquid smoke, tofu, natural preservative, organoleptic, total volatile base (TVB)

\section{Pendahuluan}

Aceh merupakan salah satu provinsi di Indonesia sebagai penghasil kelapa sawit dengan luas perkebunan rakyat mencapai 413.873 ha pada tahun 2014. Banyaknya industri minyak kelapa sawit menyebabkan limbah yang dihasilkan sangat besar dimana jika limbah tersebut tidak dimanfaatkan akan menggangu lingkungan. Limbah kelapa sawit berupa tandan kosong, batang, cangkang dan pelepah yang merupakan sisa dari pengolahan industri sawit saat ini belum dimanfaatkan secara maksimal. Seiring berkembangnya ilmu pengetahuan dan teknologi, maka limbah cangkang sawit dapat diolah menjadi produk 
yang bernilai ekonomi lebih tinggi yaitu menjadi asap cair.

Proses yang digunakan untuk menghasilkan asap cair adalah pirolisis. Kandungan asap cair dari hasil pirolisis adalah senyawa fenol sebesar 4,13\%, karbonil $11,3 \%$ dan asam 10,2\%, senyawa tersebut bersifat antimikroba yang dapat mengawetkan makanan [1]. Sifat antimikroba tersebut dapat menghambat aktivitas mikroba perusak dan pembusuk pada makanan sehingga dapat memperpanjang masa simpan produk makanan [9]. Selain itu asap cair juga dapat memberikan efek terhadap rasa, warna, dan aroma yang khas. Beberapa jenis limbah pertanian seperti tongkol jagung, sekam padi, kulit kacang tanah, tempurung kelapa, sabut kelapa, kayu mangrove, pinus dan lain lain memiliki kandungan fenol dan antibakteri yang dapat mengawetkan dan memberi rasa pada produk makanan $[2,8]$. Penggunaan asap cair sebagai pegawet alami diharapkan dapat menggantikan pengawet buatan yang selama ini banyak digunakan.

Tahu merupakan makanan yang disukai di Indonesia. Kandungan Protein dan air yang tinggi dalam tahu dapat mengakibatkan tahu mudah rusak karena ditumbuhi mikroba sehingga tahu hanya bertahan maksimal 2 hari [5]. Tahu merupakan makanan yang memiliki kandungan gizi tinggi, terutama protein. Saat ini formalin dan boraks banyak dicampurkan kedalam makanan agar makanan tersebut dapat awet. Beberapa contoh makanan yang menggunakan pengawet formalin adalah mie basah, daging ayam, ikan asin, tahu dan sebagainya. Penambahan zat kimia tersebut dengan kadar yang berebihan pada makanan dapat bersifat toksik dan membahayakan kesehatan manusia.

Tahu merupakan bahan makanan yang bersifat mudah rusak, maka perlu adanya solusi untuk memperpanjang usia penyimpanannya agar lebih tahan lama. Penelitian ini bertujuan untuk mengetahui kemampuan asap cair sebagai pengawet alami tahu.

\section{Teori}

Pabrik Farmasi di Kansas memproduksi asap cair untuk pertama kalinya pada tahun 1980 dengan menggunakan dengan metode kasar dari distilasi kayu asap[8]. Produk yang berupa asap cair kemudian digunakan untuk mengawetkan produk daging dan untuk memberi citarasa pada beberapa bahan makanan.

Asap cair terdiri larutan dari dispersi asap dalam air yang dihasilkan dengan mengkondensasikan asap hasil pirolisis pada suhu air $25{ }^{\circ} \mathrm{C}$ [1]. Komponen komponen penyusun asap cair meliputi: senyawa-senyawa fenol, karbonil, asam, dan hidrokarbon polisiklis aromatis [6]. Penelitian sebelumnya menunjukkan bahwa golongan-golongan senyawa penyusun asap cair adalah air (11$92 \%)$, fenol $(0,2-2,9 \%)$, asam $(2,8-9,5 \%)$, karbonil $(2,6-4,0 \%)$ dan $\operatorname{tar}(1-7 \%)$ [4]

\section{Metodologi Penelitian}

\section{a. Pembuatan Asap Cair}

Bahan baku (cangkang kelapa sawit) dimasukkan sebanyak $5 \mathrm{~kg}$ dalam reaktor pirolisis, kemudian sampel dipirolisis pada Temperatur $300^{\circ} \mathrm{C}, \quad 340^{\circ} \mathrm{C}, \quad 380^{\circ} \mathrm{C}$ untuk menghasilkan asap yang selanjutnya dikondensasikan dengan menggunakan kondensor sehingga menghasilkan asap cair Grade 3, tar, dan arang. Selanjutnya asap cair yang dihasilkan dimurnikan secara distilasi pada temperatur $180^{\circ} \mathrm{C}-200^{\circ} \mathrm{C}$ untuk memisahkan asap cair dengan tar sehingga menghasilkan asap cair Grade 1. Skema peralatan asap cair dapat ditabulasikan pada gambar 1 .

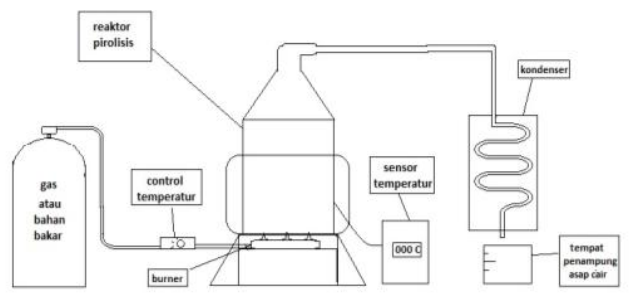

Gambar 1. Skema pembuatan Asap Cair Alat Pirolisis asap cair

Asap cair yang diperoleh kemudian digunakan sebagai pengawet tahu pada konsentrasi $0,5 \%, 1 \%, 2 \%, 4 \%$ dan $6 \%$ dan diamati masa ketahanan tahu setiap 4 jam dengan uji organoleptik sedangkan pada Uji TVB pengamatan dilakukan setiap 8 jam.

\section{b. Pengawetan Tahu}

Asap cair yang dihasilkan kemudian diencerkan konsentrasinya menjadi $0,5 \%, 1 \%$, $2 \%, 4 \%$ dan $6 \%$. Selanjutnya asap cair tersebut digunakan sebagai pengawet tahu dengan cara direndam ke dalam asap cair tersebut. Tahu yang sudah melalui proses pengawetan kemudian diamati masa penyimpanannya selama 4 jam, kemudian dilakukan uji kandungan TVB dan Organoleptik. 


\section{c. Pengujian Total Volatile Base (TVB)}

Uji TVB-N dilakukan berdasarkan SNI-014495-1998. Sampel tahu yang telah dihaluskan ditimbang sebanyak $2 \mathrm{~g}$. Kemudian sampel dimasukkan ke dalam blender dan ditambah 75 ml larutan TCA 7\% dan dihaluskan kembali selama 1 menit. Selanjutnya sampel disaring dan diuji kadar TVB-Nnya. $1 \mathrm{ml}$ asam borat dimasukkan ke dalam inner chamber cawan conway, kemudian filtrat sampel dimasukkan ke bagian luar cawan conway. Selanjutnya, cawan conway ditutup, lalu ditambahkan $1 \mathrm{ml}$ larutan K2CO3 pada bagian luar. Bagi blanko, filtrat dianti dengan larutan TCA 5\%. Inkubasi sampel pada suhu $35^{\circ} \mathrm{C}$ selama 2 jam. Setelah diinkubasi bagian dalam cawan conway, baik pada blanko maupun sampel, dititrasi dengan $\mathrm{HCl} 0,02 \mathrm{~N}$ sampai berwarna merah muda seperti pada blanko. Hasil titrasi dicatat dan dimasukkan dengan perhitungan:

TVB $(\mathrm{mgN} \%)=\underline{(\text { Vsampel-Vblanko }) \times \mathrm{N} \mathrm{HCl} \times 14,007 \times 100}$ Berat sampel

\section{d. Pengujian Organoleptik}

Pengujian organoleptik merupakan uji yang dipengaruhi atau berdasarkan penggunaan alat indra. Pengindraan dapat diartikan suatu proses fisio-psikologis yang merupakan proses pengenalan alat - alat indra terhadap sifat benda yang timbul karena adanya rangsangan yang diterima alat indra dari benda tersebut. Alat indra yang digunakan adalah lidah (pengecap rasa), mata (melihat warna) dan hidung (penguji bau). Reaksi yang ditimbulkan dapat berupa mendekati atau menjauhi, menyukai atau tidak menyukai benda penyebab rangsangan [11].

\section{Hasil dan Pembahasan}

Pengaruh temperatur pirolisis terhadap yield asap cair pada gambar 2 menunjukkan bahwa pada temperatur pirolisis $340^{\circ} \mathrm{C}$ menghasilkan yield asap cair yang paling tinggi yaitu 45,81 , hal ini disebabkan semakin tinggi temperatur pirolisis yang digunakan maka semakin lama yang dibutuhkan reaktor untuk mencapai temperatur tersebut sehingga cangkang sawit yang ada di dalam reaktor sudah terpirolisis sebagian.

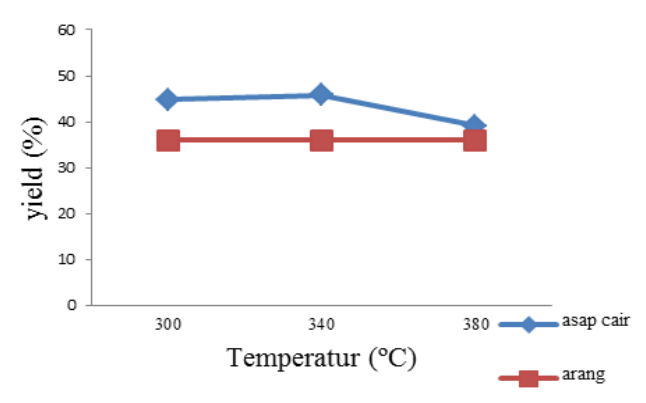

Gambar 2. Pengaruh temperatur pirolisis terhadap yield asap cair

\section{Uji TVB}

Nilai TVB merupakan salah satu parameter yang digunakan untuk melihat kualitas dari bahan makanan. Suatu bahan makanan akan dianggap sudah tidak layak makan apabila nilai TVB sudah melebihi batas penerimaan (30-35 mgN\%) [9]. Hasil analisa uji TVB yang telah dilakukan pada tiap masing-masing konsentrasi dan temperatur dapat kita lihat pada Gambar 2. Tahu yang tidak direndam menggunakan asap cair hanya bertahan selama 32 jam namun tahu yang direndam menggunakan asap cair mampu bertahan hingga 72 jam. Di dalam proses pengawetan tahu menggunakan asap cair, konsentrasi dan temperatur asap cair sangat berpengaruh terhadap umur simpan suatu produk makanan, semakin tinggi konsentrasi asap cair maka proses pengawetan akan semakin lama. Tahu akan tahan selama 72 jam pada konsentrasi asap cair $2 \%$, namun penelis tidak menyukai karena pada keadaan ini rasa dan aroma yang begitu menyengat. Pada temperatur $340^{\circ} \mathrm{C}$ dan konsentrasi $0,5 \%$ diperoleh nilai TVB pada kondisi ini adalah $19,61 \mathrm{mgN} \%$, pada kondisi ini tahu masih layak untuk dikonsumsi. Pengaruh konsentrasi asap cair pada tiap temperatur terhadap umur simpan tahu ditabulasikan pada Gambar 3. 


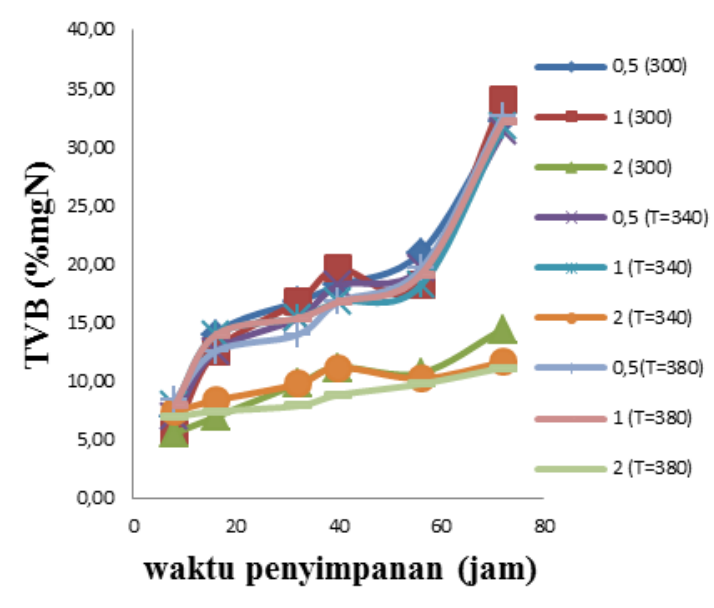

Gambar 3.Pengaruh konsentrasi asap cair pada tiap temperatur terhadap umur simpan

\section{Uji Organoleptik}

Pengujian sifat organoleptik merupakan metode uji yang sangat penting bagi setiap prduk makanan karena berkaitan dengan penerimaan konsumen. Uji kesukaan dilakukan pada penelitian ini yaitu dari segi warna, aroma, tekstur dan rasa yang bertujuan untuk mengetahui sejauh mana tingkat kesukaan panelis terhadap produk tahu. Pengujian organoleptik dilakukan dengan memberikan kuisioner kepada 30 orang panelis (umum) yang akan menilai produk tahu yang direndam dengan variasi konsentrasi asap cair.

\section{a.Warna}

Warna didefinisikan sebagai atribut mutu yang ditangkap oleh mata konsumen sebelum penilaian atribut mutu yang lain dari produk. Warna dapat memberikan petunjuk mengenai perubahan kimia dalam makanan sehingga dapat dijadikan salah satu faktor penentu penting dalam penerimaan produk makanan. Hasil pengujian organoleptik ditampilkan pada tabel 1.

Dari tabel 1 dapat dilihat bahwa tahu yang direndam dengan asap cair dengan konsentrasi 0,5\% menghasilkan tahu dengan warna putih bersih. Hasil pengisian kuisioner diperoleh sebanyak 25 orang panelis menyukai tahu yang berwarna putih bersih dan tidak pucat.
Tabel 1. Hasil pengujian organoleptikwarna pada produk tahu

\begin{tabular}{|c|c|c|c|c|c|}
\hline $\begin{array}{c}\text { Suhu } \\
\text { Pirolisis }\end{array}$ & $\begin{array}{c}\text { Konsentrasi Asap } \\
\text { Cair }\end{array}$ & \multicolumn{4}{|c|}{ Warna (jam) } \\
\cline { 2 - 6 } & $0,5 \%$ & 4 & 8 & 12 & 16 \\
\hline \multirow{4}{*}{$300{ }^{\circ} \mathrm{C}$} & $1 \%$ & 3 & 3 & 3 & 3 \\
\cline { 2 - 6 } & $2 \%$ & 3 & 3 & 2 & 3 \\
\cline { 2 - 6 } & $4 \%$ & 3 & 3 & 3 & 3 \\
\cline { 2 - 6 } & $6 \%$ & 3 & 3 & 3 & 3 \\
\hline \multirow{3}{*}{$340{ }^{\circ} \mathrm{C}$} & $0,5 \%$ & 5 & 5 & 5 & 5 \\
\cline { 2 - 6 } & $1 \%$ & 5 & 5 & 4 & 4 \\
\cline { 2 - 6 } & $2 \%$ & 4 & 4 & 4 & 4 \\
\cline { 2 - 6 } & $4 \%$ & 3 & 3 & 2 & 2 \\
\cline { 2 - 6 } & $6 \%$ & 3 & 3 & 2 & 2 \\
\hline \multirow{3}{*}{$380^{\circ} \mathrm{C}$} & $0,5 \%$ & 4 & 3 & 3 & 3 \\
\cline { 2 - 6 } & $1 \%$ & 4 & 4 & 3 & 3 \\
\cline { 2 - 6 } & $2 \%$ & 3 & 3 & 2 & 2 \\
\cline { 2 - 6 } & $4 \%$ & 3 & 3 & 2 & 2 \\
\cline { 2 - 6 } & $6 \%$ & 3 & 3 & 2 & 2 \\
\hline
\end{tabular}

Keterangan:

Coklat:1,Coklat Muda: 2, Kream: 3, Agak kream:4,dan Putih: 5

\section{b. Rasa dan Bau}

Bau atau aroma merupakan hasil respon dari hidung yang diakibatkan oleh menguapnya zat-zat larut yang terkandung pada suatu produk makanan ke udara sehingga dikenali sebagai aroma tertentu. Pengujian rasa dan aroma sangat penting dalam industri makanan, karena dapat memberikan hasil penilaian langsung tentang produk makanan yang lebih diminati oleh konsumen [4]. Hasil pengujian rasa dan aroma ditabulasikan pada tabel 2

Tabel 2. Hasil pengujian organoleptik produk tahu

\begin{tabular}{|c|c|c|c|c|c|c|c|c|c|}
\hline \multirow[t]{2}{*}{ Suhu } & \multirow{2}{*}{$\begin{array}{c}\text { Konsentr } \\
\text { asi Asap } \\
\text { Cair }\end{array}$} & \multicolumn{4}{|c|}{ Rasa (jam) } & \multicolumn{4}{|c|}{ Bau (jam) } \\
\hline & & 4 & 8 & 12 & 16 & 4 & 8 & 12 & 16 \\
\hline \multirow{5}{*}{$300{ }^{\circ} \mathrm{C}$} & $0,5 \%$ & 4 & 4 & 3 & 3 & 4 & 4 & 4 & 4 \\
\hline & $1 \%$ & 4 & 4 & 3 & 3 & 4 & 4 & 3 & 3 \\
\hline & $2 \%$ & 3 & 3 & 3 & 3 & 3 & 3 & 3 & 3 \\
\hline & $4 \%$ & 3 & 3 & 3 & 3 & 3 & 3 & 3 & 3 \\
\hline & $6 \%$ & 3 & 3 & 3 & 3 & 2 & 2 & 2 & 2 \\
\hline \multirow{5}{*}{$340{ }^{\circ} \mathrm{C}$} & $0,5 \%$ & 5 & 5 & 5 & 4 & 5 & 5 & 5 & 5 \\
\hline & $1 \%$ & 5 & 5 & 4 & 4 & 4 & 4 & 4 & 4 \\
\hline & $2 \%$ & 4 & 4 & 4 & 4 & 4 & 4 & 3 & 3 \\
\hline & $4 \%$ & 3 & 3 & 3 & 3 & 2 & 2 & 2 & 2 \\
\hline & $6 \%$ & 3 & 3 & 3 & 3 & 2 & 2 & 2 & 2 \\
\hline \multirow{5}{*}{$380^{\circ} \mathrm{C}$} & $0,5 \%$ & 4 & 4 & 4 & 4 & 3 & 3 & 3 & 3 \\
\hline & $1 \%$ & 4 & 4 & 4 & 4 & 3 & 3 & 3 & 3 \\
\hline & $2 \%$ & 3 & 3 & 3 & 3 & 2 & 2 & 2 & 2 \\
\hline & $4 \%$ & 2 & 2 & 2 & 2 & 2 & 2 & 2 & 2 \\
\hline & $6 \%$ & 2 & 2 & 2 & 2 & 2 & 2 & 2 & 2 \\
\hline
\end{tabular}

Keterangan:

Rasa

Sangat tidak enak: 1, Tidak enak: 2, Sedang: 3, Enak: 4 dan Sangat enak: 5 .

Bau

Sangat Bau: 1, Bau: 2, Sedang: 3, Sedikit Bau: 4 dan Tidak Bau: 5.

Tabel 2 menunjukkan bahwa yang banyak diminati oleh panelis adalah produk tahu yang diawetkan dengan konsentrasi asap cair 0,5\% dan suhu pirolisis $340{ }^{\circ} \mathrm{C}$. Tahu yang dihasilkan memiliki aroma asap, rasa tahu alami dan tidak asam. Aroma asap pada tahu timbul dari asap cair yang meresap pada lapisan tahu. Aroma yang tidak enak juga dapat digunakan sebagai 
indikasi terjadinya kerusakan pada produk, yang disebabkan proses produksi dan penyimpanan yang tidak baik.

\section{c. Tekstur}

Pengujian tekstur dilakukan dengan menggunakan mulut dan bisa juga dengan tangan. Uji ini bertujuan untuk merasakan tekstur suatu produk makanan. Tabel 3 menunjukkan bahwa tekstur tahu yang direndam dengan konsentrasi asap cair dengan temperatur pirolisis $340^{\circ} \mathrm{C}$ menghasilkan tahu dengan tekstur yang lembut dibandingkan dengan temperatur pirolisis lainnya yang menghasilkan tekstur tahu yang keras. Hasil pengujian organoleptik menunjukkan bahwa sekitar 28 orang panelis atau sekitar $95 \%$ menyukai tekstur tahu yang direndam asap cair dengan konsentrasi $0,5 \%$. Pada umumnya konsumen menyukai tekstur tahu yang lembut, karena biasanya tekstur makanan yang keras dan kenyal sering diindikasikan menggunakan pengawet yang berbahaya pada produk makanan.

Tabel 3. Hasil pengujian organoleptik produk tahu

\begin{tabular}{|c|c|c|c|c|c|}
\hline Suhu & Konsentrasi Asap & \multicolumn{4}{|c|}{ Tekstur (jam) } \\
\cline { 2 - 6 } & Cair & 4 & 8 & 12 & 16 \\
\hline \multirow{4}{*}{$300{ }^{\circ} \mathrm{C}$} & $0,5 \%$ & 3 & 3 & 3 & 3 \\
\cline { 2 - 6 } & $1 \%$ & 3 & 3 & 3 & 3 \\
\cline { 2 - 6 } & $2 \%$ & 3 & 3 & 3 & 3 \\
\cline { 2 - 6 } & $4 \%$ & 3 & 3 & 3 & 3 \\
\hline \multirow{4}{*}{$340{ }^{\circ} \mathrm{C}$} & $6 \%$ & 3 & 3 & 3 & 3 \\
\cline { 2 - 6 } & $0,5 \%$ & 5 & 5 & 5 & 5 \\
\cline { 2 - 6 } & $1 \%$ & 4 & 4 & 4 & 4 \\
\cline { 2 - 6 } & $2 \%$ & 3 & 3 & 3 & 3 \\
\cline { 2 - 6 } & $4 \%$ & 3 & 3 & 3 & 3 \\
\hline \multirow{3}{*}{$380^{\circ} \mathrm{C}$} & $6 \%$ & 2 & 2 & 2 & 2 \\
\cline { 2 - 6 } & $0,5 \%$ & 2 & 2 & 2 & 2 \\
\cline { 2 - 6 } & $1 \%$ & 2 & 2 & 2 & 2 \\
\cline { 2 - 6 } & $2 \%$ & 2 & 2 & 2 & 2 \\
\cline { 2 - 6 } & $4 \%$ & 2 & 2 & 2 & 2 \\
\cline { 2 - 6 } & $6 \%$ & 2 & 2 & 2 & 2 \\
\hline
\end{tabular}

Keterangan:

Keras: 1, Agak Keras: 2, Kaku: 3, Sedikit kaku: 4 dan Lembut: 5 .

\section{Kesimpulan}

Berdasarkan penelitan yang telah dilakukan maka dapat diambil beberapa kesimpulan sebagai berikut :

1. Yield asap cair yang dihasilkan pada suhu $300{ }^{\circ} \mathrm{C}, 340{ }^{\circ} \mathrm{C}$ dan $380{ }^{\circ} \mathrm{C}$ adalah $44.85 \%$, $45.81 \%$ dan $39.15 \%$;

2. Asap cair dari cangkang kelapa sawit mampu menjadi pengawet produk makanan tahu;

3. Kondisi terbaik untuk pengawetan tahu diperoleh pada temperatur $340{ }^{\circ} \mathrm{C}$ konsentrasi $0.5 \%$ dengan nilai TVB 19,61 $\mathrm{mgN} \%$;

4. Sekitar $90 \%$ responden menyukai rasa, aroma dan tekstur tahu yang direndam dengan asap cair yang dipirolisis pada suhu
$340{ }^{\circ} \mathrm{C}$ dengan konsentrasi $0,5 \%$.

\section{Daftar Pustaka}

[1]. Darmadji., Aktivasi Anti Bakteri Asap Cair yang Diproduksi dari Bermacammacam Limbah Pertanian, Agritech, Vol 16, No.4, (1999) 19 - 22.

[2]. Doherty and Cohn., 2000. Commercial Liquid Smoke Elicits Germination http://www.cabi.com.

[3]. E.Himawati., Pengaruh Penambahan Asap Cair Tempurung Kelapa Destilasi dan Redestilasi Terhadap Sifat Kimia, Mikrobiologis, dan Sensoris Ikan Pindang Layang (Decapterus spp) Selama Penyimpanan,

[4]. F. Fatimah., Analisa Komponen Komponen Penyusun Asap Cair Tempurung Kelapa (1998)

[5]. I. Mahmudah. Peningkatan Umur Simpan Tahu Menggunakan Bubuk Kunyit serta Analisa Usaha dan Konsentrasi Bubuk Kunyit (2007).

[6]. J.A. Maga., Smoke in food Processing, (1987) 1.

[7]. M. D. Guillen; N.Cabo., (2004).

[8]. Pszczola, E. Donald. Tour Highlights Production and Uses of Smoke-Based Flavors49 (1995) 70.

[9]. R.,Fransiska., Optimasi Produksi Asap Cair Cangkang Biji Jarak Pagar dan Aplikasinya pada Pengawetan Ikan Nila (Oreochromis niloticus) asa (2009).

[10]. Y.Ozgul., Methods for deterioration. In: . Seafood and seafood productsanalysis productsanalysis (2010)189.

[11]. http://tekpan.unimus.ac.id/wp-content/ uploads/2014/03/Uji-Organoleptik- Produk -Pangan.pdf .diakses November 2014. 